\title{
Resurrection of Pareiorhaphis Miranda Ribeiro, 1918 (Teleostei: Siluriformes: Loricariidae), and description of a new species from the rio Iguaçu basin, Brazil
}

\author{
Edson H. Lopes Pereira
}

\begin{abstract}
A new species of the loricariid subfamily Neoplecostominae is described on the basis of specimens obtained from the headwaters of the rio Iguaçu basin in the State of Paraná, southern Brazil. Pareiorhaphis parmula is the first representative of the genus discovered from the rio Paraná basin and expands the geographic distribution of the genus. It is diagnosed from other Pareiorhaphis species by having one small plate on each side of the pectoral girdle, just posterior to the gill opening and the club-shaped pectoral-fin spine, broadening from base to tip in adult males. All species formerly included in Hemipsilichthys except $\mathrm{H}$. gobio, H. papillatus, and H. nimius are transferred to the genus Pareiorhaphis, which is resurrected from the synonymy of Hemipsilichthys.

Uma nova espécie de loricarídeo pertencente a subfamília Neoplecostominae é descrita com base em espécimes obtidos das cabeceiras do rio Iguaçu, estado do Paraná, sul do Brasil. Pareiorhaphis parmula é a primeira espécie do gênero descrita para a bacia do rio Paraná expandindo a distribuição do gênero. Se diferencia das demais espécies do gênero pela presença de uma única e pequena placa na região ventral posterior a abertura branquial e pelo formato de clava do raio indiviso da nadadeira peitoral, estreito na base e alargando-se em direção à extremidade do raio em machos adultos. Todas as espécies previamente incluídas em Hemipsilichthys com exceção de H. gobio, H. papillatus e H. nimius são transferidas para o gênero Pareiorhaphis, que é retirado da sinonímia de Hemipsilichthys.
\end{abstract}

Key words: Neotropical, Systematics, Neoplecostominae, Hemipsilichthys, Isbrueckerichthys.

\section{Introduction}

The complex taxonomic history of Pareiorhaphis Miranda Ribeiro, 1918 allied to recent discoveries on their phylogenetic relationships warrant some explanatory comments. Most species herein being transferred to Pareiorhaphis were originally described in Hemipsilichthys Eigenmann \& Eigenmann, 1889. Several new Hemipsilichthys species were described during the 20th century, including H. duseni Miranda Ribeiro, 1907. This description was based on three syntypes, one from Paraná State and two from the ribeirão do Monjolinho (rio Iporanga basin, State of São Paulo). A few years later Miranda Ribeiro (1918) proposed the new genus Pareiorhaphis for $H$. duseni, H. steindachneri Miranda Ribeiro, 1918, and $H$. calmoni (Steindachner, 1907), without designating a type-species. Apparently, only Gosline (1947), when reexamining the three syntypes of $H$. duseni, recognized two species among them. Pareiorhaphis alipionis Gosline, 1947 from the rio
Betari, Iporanga basin, was described as a second species in that genus and $H$. duseni was designated as type-species of Pareiorhaphis. Derijst (1996) discovered an earlier, previously unnoticed, type-species designation by Regan (1920), who chose Hemipsilichthys calmoni as type-species of Pareiorhaphis. As H. calmoni was a valid species in Hemipsilichthys, this earlier designation made Pareiorhaphis a junior synonym of Hemipsilichthys and the two species allocated in Pareiorhaphis were left without a valid genus name. Based on these findings, Derijst (1996) transferred $P$. duseni and $P$. alipionis into his new genus Isbrueckerichthys Derijst, 1996.

Pereira \& Reis (2002) recently produced a taxonomic revision of the genera Hemipsilichthys and Isbrueckerichthys. Eighteen species were recognized in Hemipsilichthys, including the type species of the genus, H. gobio (Luetken, 1874) from the rio Paraíba do Sul basin, while only two species of Isbrueckerichthys were recognized in the rio Ribeira de Iguape

Museu de Ciências e Tecnologia, PUCRS, P. O. Box 1429, 90619-900 Porto Alegre, RS, Brazil. e-mail: edson.pereira@pucrs.br 
drainage. The species of Isbrueckerichthys were distinguished from Hemipsilichthys by having the abdomen with several small, scattered platelets, while all Hemipsilichthys species have the abdomen completely naked. In 2003 two new species were described: Hemipsilichthys nimius Pereira, Reis, Souza \& Lazzarotto, 2003 from the upper rio Perequê-Açú in southern coast of Rio de Janeiro State and Isbrueckerichthys epakmos Pereira \& Oyakawa, 2003 from the rio Ribeira de Iguape basin in São Paulo State.

Montoya-Burgos et al. $(1998,2001)$ and Armbruster (2004), demonstrated that the type-species of Hemipsilichthys, $H$. gobio, is basal relative to most other loricariids. In additional, Armbruster (2004) found support to hypothesize that Delturus angulicauda (Steindachner, 1877) and Hemipsilichthys gobio form the monophyletic sister group to all other loricariids except Lithogenes Eigenmann, 1909. Reis et al. (in press) expanded Armbruster's findings and described a new subfamily to accommodate the genus Delturus and three species of Hemipsilichthys. The above papers also show that the other species of what is usually termed Hemipsilichthys cluster together forming a clade with a number of other genera, deeply nested within the loricariid phylogeny. The recognition that the type-species of Hemipsilichthys is not related to most other species currently assigned to the genus, except for $H$. papillatus Pereira, Oliveira \& Oyakawa, 2000 and $H$. nimius, makes Pareiorhaphis the next available name to contain the remaining species up to now assigned to Hemipsilichthys. Whether Pareiorhaphis is monophyletic or not is beyond the scope of this paper and is deferred to another article in preparation.

For this reason, the new species is described in Pareiorhaphis and H. calmoni, H. garbei Ihering, 1911, H. steindachneri, H. regani Giltay, 1936, H. bahianus (Gosline, 1947), H. cerosus Miranda Ribeiro, 1951, H. vestigipinnis Reis \& Pereira, 1992, H. splendens Bizerril, 1995, H. mutuca Oliveira \& Oyakawa, 1999, H. stephanus Oliveira \& Oyakawa, 1999, $H$. nudulus Reis \& Pereira, 1999, H. azygolechis Pereira \& Reis, 2002, H. eurycephalus Pereira \& Reis, 2002, H. hystrix Pereira \& Reis, 2002, H. hypselurus Pereira \& Reis, 2002, and $H$. stomias Pereira \& Reis, 2002 are herein transferred to Pareiorhaphis, while Hemipsilichthys gobio, H. papillatus, and $H$. nimius remain as the only valid species in Hemipsilichthys.

Recent joint collections by MCP and MHNCI have resulted in additional material of Pareiorhaphis from the upper reaches of the rio Iguaçu basin, in the State of Paraná, southern Brazil. The comparison of the recently collected material with other species allowed the recognition of a new species that clearly contrast with all other species of the genus. This species represents the first record of a Pareiorhaphis in the rio Paraná basin and this discovery is an indication that additional new species are likely to be found in other headwater tributaries of the rio Paraná. In this paper I provide a formal description of that species diagnosing it from the remaining Pareiorhaphis species and discuss the reasons for including the new species in the genus Pareiorhaphis.

\section{Material and Methods}

The examined specimens are deposited in the Museu de Ciências e Tecnologia, Pontifícia Universidade Católica do Rio Grande do Sul, Porto Alegre (MCP) and Museu de História Natural Capão da Imbuia, Curitiba (MHNCI). Measurements were made from point to point with a digital calipers, under a dissecting microscope. Measurements and counts of bilaterally symmetrical features were taken from the left side of the body whenever possible; if a feature was missing or broken on the left side, it was examined on the right side. Measurements follow Weber (1985) and Pereira et al. (2003). Body plate counts and nomenclature were taken according to Schaefer (1997). Additional counts include: (1) median plate series (number of plates with the lateral line, counted from the posterior process of compound pterotic to last plate in median series, but not including the horizontally elongate plates covering the insertion of the middle caudal fin rays), and were counted in both sides; (2) plates lateral to dorsal-fin base (number of plates in dorsal series along the dorsal-fin base); (3) plates between dorsal and adipose fins (number of plates in dorsal series between last dorsal-fin branched ray insertion and origin of adipose-fin spine); (4) plates between adipose and caudal fins (number of plates in dorsal series from just posterior the adipose-fin membrane to the caudal fin); (5) plates lateral to anal-fin base (number of plates in ventral series along the anal-fin base); (6) plates between anal and caudal fins (number of plates in ventral series between the last anal-fin branched ray insertion to caudal fin); (7) pre-adipose unpaired plates (number of unpaired plates preceding the insertion of the adipose-fin spine); (8) premaxillary and dentary teeth (number of teeth counted separately in both sides).

Standard length is expressed in $\mathrm{mm}$. All other measurements are expressed as percents of standard length, except subunits of the head which are expressed as percents of head length. In the list of type material museum acronym and cata$\log$ number come first, followed by the number of specimens in that lot, the number of specimens measured for the morphometric comparisons in parentheses, the range of standard length, locality, date of collection, and collectors. Abbreviations used are SL (standard length) and HL (head length).

\section{Results}

\section{Pareiorhaphis parmula, new species}

Fig. 1

Holotype. MCP 35826, male, 93.3 mm SL; Brazil: Paraná: Lapa: rio Iguaçu basin: rio dos Patos, tributary to rio da Várzea, on road PR-427 from Lapa to Campo do Tenente, 2550'36.8"S 04943’39.2"W, 29 Oct 2004, E. H. L. Pereira, L. F. Duboc, V. Abilhôa, and R. Torres. Paratypes. Brazil: Paraná: MCP 35827 , $59+2$ c\&s (29) 45.7-94.5 mm SL and MHNCI 10883, 3 (1) 59.6$73.6 \mathrm{~mm}$ SL; all collected with the holotype. MCP 35556, 10 (7) 


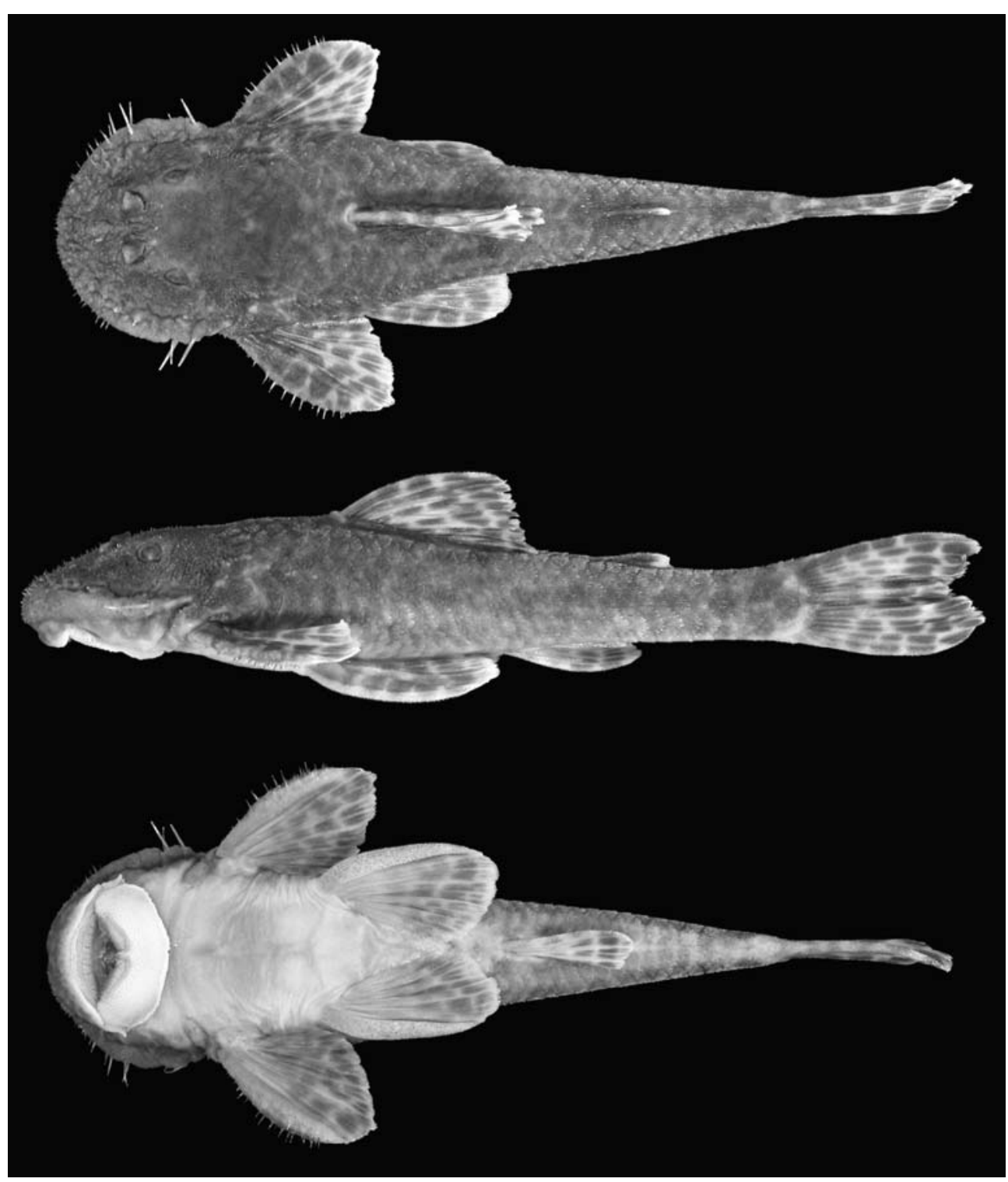

Fig. 1. Pareiorhaphis parmula, holotype, MCP 35826 male, 93.3 mm SL. Brazil: Paraná: Lapa: rio Iguaçu basin: rio dos Patos, tributary of rio da Varzea.

39.6-86.5 mm SL; rio dos Patos, tributary to rio da Várzea, Lapa, 2550’38"S 04943'39"W, 3 Jul 2004, V. Abilhôa \& L. F. Duboc.

Diagnosis. Pareiorhaphis parmula can be distinguished from all other Pareiorhaphis species by having one small plate on each side of the pectoral girdle, just posterior to the gill opening ( $v s$. abdomen totally naked in all other species). The clubshaped pectoral-fin spine, broadening from base to apex on adult males, also distinguishes $P$. parmula from other Pareiorhaphis species with the exception of $P$. vestigipinnis. From $P$. vestigipinnis, the new species can be distinguished by having an adipose fin.

Pareiorhaphis parmula can be further distinguished from $P$. vestigipinnis, $P$. stephane, $P$. nudula, and $P$. regani by the longer caudal peduncle (34.4-37.9 vs. 27.9-34.0\% SL); from $P$. eurycephalus, $P$. hypselurus, $P$. stomias, and $P$. splendens by the smaller cleithral width (27.9-31.0 vs. 32.1-40.0\% SL); from P. cerosa, P. bahiana, P. azygolechis, and $P$. mutuca by the smaller caudal peduncle depth (8.2-9.2 vs. 9.4-11.7\% SL); from $P$. garbei, $P$. calmoni, and $P$. hystrix by the number of dentary teeth (32-48 vs. 60-89, 49-84 and 42-57, respectively); from $P$. steindachneri by having the longest hypertrophied odontodes on cheeks of mature males shorter than interorbital width ( $v s$. longer than interorbital width).

Description. Counts and proportional measurements presented in Table 1. Standard length of measured specimens 43.5 to $94.5 \mathrm{~mm}$. See Fig. 1 for general body aspect. Dorsal surface of body covered by plates except for naked area around dorsal fin. Body moderately depressed. Progressively narrowing from cleithrum to end of caudal peduncle. Dorsal profile of body slightly convex, rising from snout tip to origin of dorsal fin and then descending to end of caudal peduncle. 
Table 1. Descriptive morphometrics and meristics of Pareiorhaphis parmula. Values are given as ranges for all measured specimens. Standard length is expressed in $\mathrm{mm}$.

\begin{tabular}{|c|c|c|c|c|c|}
\hline Character & Holotype & $\mathrm{N}$ & Range & Mean & SD \\
\hline Standard length $(\mathrm{mm})$ & 93.3 & 29 & $43.5-94.5$ & 68.4 & 10.421 \\
\hline \multicolumn{6}{|c|}{ Percents of Standard length } \\
\hline Head length & 29.5 & 29 & $29.4-33.6$ & 31.5 & 1.081 \\
\hline Predorsal length & 40.7 & 29 & $41.5-45.0$ & 43.1 & 0.835 \\
\hline Postdorsal length & 42.7 & 29 & $39.5-44.5$ & 41.5 & 1.251 \\
\hline Dorsal-fin spine length & 21.8 & 26 & $19.6-23.0$ & 21.1 & 0.879 \\
\hline Anal-fin spine length & 17.1 & 28 & $14.3-17.2$ & 15.3 & 0.643 \\
\hline Pectoral-fin spine length & 18.8 & 29 & $17.2-19.6$ & 18.4 & 0.608 \\
\hline Pelvic-fin spine & 22.1 & 29 & 18.6 & 21.2 & 0.956 \\
\hline Uppermost caudal-fin ray & 23.6 & 27 & 21.8 & 23.6 & 0.986 \\
\hline Lowe & 24.3 & 29 & 22.8 & .7 & 1.036 \\
\hline & 7.8 & 26 & & 9 & 0.683 \\
\hline Tho & 16.2 & 28 & 15.8 & 17.5 & 0.794 \\
\hline Abdor & 24.5 & 29 & $23.2-27.8$ & 25.3 & 1.164 \\
\hline $\mathrm{C}$ & 28.8 & 29 & 27.5 & 29.6 & 0.717 \\
\hline anal-fin origin & 6 & 29 & 13. & 14.5 & 0.620 \\
\hline & 38.7 & 29 & 34. & 35.8 & 0.844 \\
\hline & & 29 & & & 0.272 \\
\hline & 5.7 & 29 & 4.1 & 5. & 0.604 \\
\hline \multicolumn{6}{|c|}{ Percents of head length } \\
\hline Snout length & 58.9 & 29 & $53.8-63.0$ & 59.0 & 1.925 \\
\hline Orbi & 13.8 & 29 & 12.7 & 14.1 & 0.795 \\
\hline rorbital width & 33.1 & 29 & 29.5 & 31.9 & 1.118 \\
\hline & & 29 & $49.5-63.8$ & 56.2 & 3.465 \\
\hline Mandibular ramus & 20.7 & 29 & $16.6-21.0$ & 19.1 & 0.942 \\
\hline Later & $30 / 30$ & 29 & & 29.6 & 0.671 \\
\hline Teeth on premaxilla & $47 / 47$ & 29 & & 39.2 & 3.804 \\
\hline Teeth on dentary & $45 / 45$ & 29 & $32-48$ & 40.2 & 3.749 \\
\hline Plates lateral to dorsal fin & 7 & 29 & $6-7$ & 6.6 & 0.494 \\
\hline & 7 & 29 & & 7.5 & 0.574 \\
\hline /caudal & 4 & 29 & & 5.1 & 0.516 \\
\hline & 3 & 29 & & 3.8 & 0.435 \\
\hline Plates between anal/caudal & 13 & 29 & $11-13$ & 12.5 & 0.574 \\
\hline
\end{tabular}

Trunk and caudal peduncle mostly ovoid in cross-section, slightly flattened ventrally and more compressed caudally. Greatest body depth at dorsal-fin origin. Least body depth at shallowest part of caudal peduncle. Ventral surface of head, region from pelvic-fin insertion to anal-fin origin, and region around anal fin completely naked. Abdomen almost totally naked, except for one (rarely two) small platelet on each side just posterior to gill opening. Plates difficult to see in specimens smaller than $50 \mathrm{~mm}$ SL.

Head broad and moderately depressed. Anterior profile of head rounded in dorsal view. Interorbital space slightly concave, nearly flattened. Three small ridges on dorsal surface of head, one median ridge from snout tip to area between nostrils, and one pair of ridges from nostril to anterior margin of orbit. Lateral margin of head covered with minute odontodes. Snout in lateral profile gently convex. Mature males with well-developed soft fleshy lobes on lateral portion of head. Soft fleshy area ornamented with short and delicate hypertrophied odontodes. Eye moderately small (12.7 to $15.9 \% \mathrm{HL}$ ), dorsolaterally placed. Iris with small dorsal flap covering pupil. Lips roundish and developed, occupying most of ventral surface of head. Lower lip almost reaching pectoral girdle and covered with minute papillae, which decrease in size towards its edge. Posterior edge slightly fringed. Maxil-

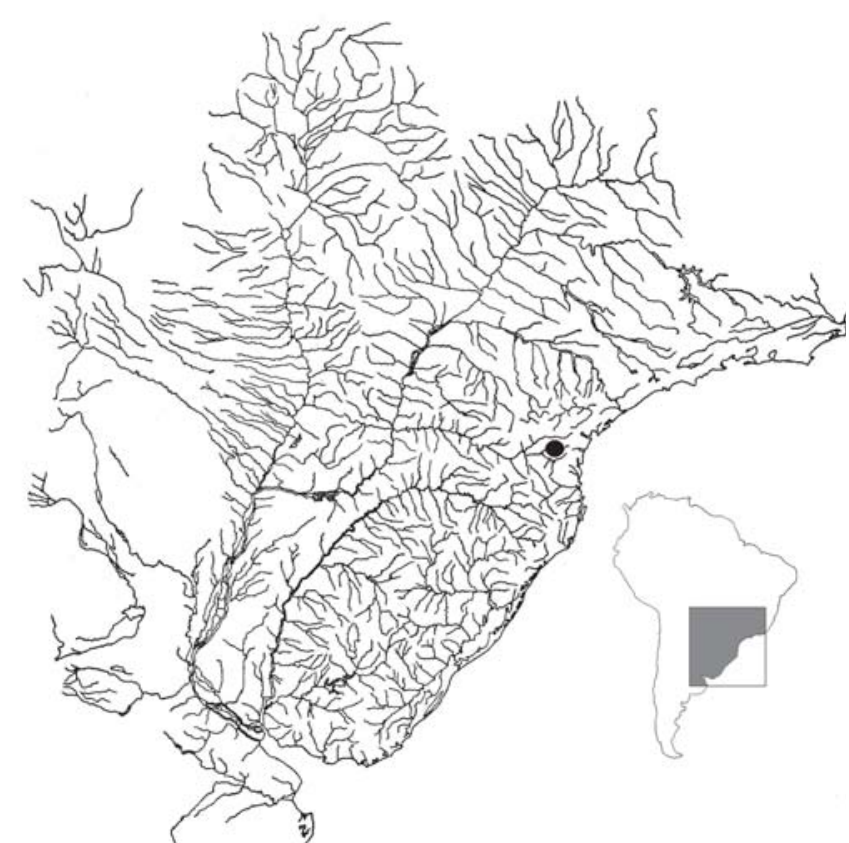

Fig. 2. Type locality of Pareiorhaphis parmula in southern Brazil.

lary barbell short and free distally (united to lip by membrane only basally). Anterior ends of premaxillae and dentaries slightly curved inwards. Teeth slender and bicuspid, inner cusp slightly curved inwards. Lateral cusp minute and pointed, never reaching half length of inner cusp.

Dorsal fin originating slightly posterior to vertical line passing through pelvic-fin origin; nuchal plate and dorsal-fin spinelet present but dorsal-fin locking mechanism non-functional. Dorsal fin spinelet oval. Dorsal-fin spine moderately flexible, followed by 7 branched rays. Adipose fin present, preceded by none to 3 median, unpaired pre-adipose azygous plates (usually 1-2). Pectoral fin of moderate size; with spine slightly curved, covered by minute odontodes in immature males and females. Mature males with pectoral-fin spine club-shaped, broadening from base to apex, bearing few straight and delicate hypertrophied odontodes on outer face; 6 branched rays. First and second branched rays slightly longer than spine. Subsequent branched rays decrease gradually in size. Posterior margin of pectoral fin may reach half length of pelvic fin when adpressed in mature males. Pelvicfin moderate in size, with one spine and 5 branched rays, tip not reaching insertion of anal fin when adpressed. Pelvic-fin spine depressed, covered with minute odontodes ventrally and laterally; dermal flap on its dorsal surface present, but not very large, extending to tip of spine in mature males. Anal fin with one unbranched and 5 branched rays. Caudal fin border concave; lower lobe slightly longer than upper; 14 branched rays. Procurrent caudal-fin rays 3-4 dorsal and 3 ventral.

Color in alcohol. Ground color of dorsal surface of body and head dark grey, sometimes light grey, whitish ventrally. Dorsum covered by dark blotches. Usually these blotches forming four irregular diffuse saddles located at origin of dorsal 
fin, behind dorsal-fin base, on adipose fin, and between adipose and caudal fins. Flanks covered by dark gray blotches, irregularly arranged and sized. Sometimes posterior half of flanks with roundish spots or indefinite mid-lateral stripe. Mature males with fleshy lobes on margin of head light gray. Spines of dorsal, pectoral, pelvic, and anal fins plain grayish or with two or three wide dark stripes. Branched rays uniformly grayish or with small, dark-brown blotches along entire length, sometimes forming two or three narrow bands. Spines and branched rays of pectoral and pelvic fins of mature males with four or five wide dark dots, sometimes forming darker irregular lines. Caudal fin with two or three narrow bands, more visible when fin widely open. Fin membranes hyaline. Ventral surface between anal-fin origin and posterior portion of lower lip pale yellow or whitish. Ventral margin of head, upper lip, and ventral portion of caudal peduncle grayish.

Distribution. Pareiorhaphis parmula is known from the rio dos Patos, headwaters of the rio Iguaçu in Paraná State, Brazil (Fig. 2).

Ecological notes. The type locality where all specimens of Pareirhaphis parmula were collected, is a small creek flowing through a landscape of mixed open field and forest. The stretch sampled is narrow (about 2-4 m wide) and shallow (about 0.4-1.0 $\mathrm{m}$ deep). The stream bottom was formed of small to medium-sized rocks, loose stones and gravel. The water was clear and moderate to fast flowing. Grass or other vegetation is usually present on the margins. The fishes are usually found among the bottom rocks and stones.

Etymology. The name parmula is Latin, diminutive from parma, meaning small, light shield, in allusion to the small plate located ventrally just behind the gill opening. A noun in apposition.

\section{Discussion}

Armbruster (2004) recognized and expanded Neoplecostominae that includes Hemipsilichthys (now Pareiorhaphis), Isbrueckerichthys, Neoplecostomus Eigenmann \& Eigenmann, 1888, Kronichthys Miranda Ribeiro, 1908, and Pareiorhina Gosline, 1947, despite the fact that these genera did not form a monophyletic assemblage, if separated from the hypoptopomatines. A phylogenetic diagnosis for Pareiorhaphis is now unavailable, but the species herein described can be included in the genus Pareiorhaphis since it shares all distinguishing features that define the genus. Pareiorhaphis can be readily distinguished from other neoplecostomines by the unique combination of the following characters: fleshy lobes on lateral margins of head ornamented with hypertrophied odontodes on nuptial males, caudal peduncle ovoid in cross-section, abdomen usually naked, dorsal-fin spinelet ovoid, and adipose-fin usually present.

The most distinctive feature of $P$. parmula is the presence of one small plate on each side of the pectoral girdle, just posterior to the gill opening. The condition present in $P$. parmula differs from that in all other species of Pareiorhaphis which have that region completely naked. Among the Neoplecostominae other genera with plates on the abdomen are Neoplecostomus and Isbrueckerichthys. The new species can be distinguished from Neoplecostomus by lacking a series of papillae on lower lip after of the dentaries and from Isbrueckerichthys by having a predorsal spinelet, always absent in the later. Pareiorhaphis parmula represents the first Pareiorhaphis species in the Paraná River basin and an increase in the geographic distribution range of the genus Pareiorhaphis.

Comparative material (in addition to that listed in Pereira \& Reis, 2002). Neoplecostomus microps: Brazil: São Paulo State: rio Paraíba do Sul basin: MCP 20069, 4, 47.1-89.3 mm SL; Ribeirão Benfica at Benfica, ca $1 \mathrm{~km}$ from Piquete. MCP 20071, 13, 45.1-98.3 mm SL; Ribeirão Macacos at Bairro dos Macacos, tributary of rio Paraitinga, Silveiras. Pareiorhina rudolphi: Brazil: São Paulo State: Piquete: rio Paraíba do Sul basin: MCP 18052, 23 + 1 c\&s, 30.4-49.3 mm SL; creek tributary of rio Piquete at Benfica. Kronichthys subteres: Brazil: São Paulo State: Iporanga: rio Ribeira de Iguape basin: MCP 20150, 32, 38.1-76.8 mm SL; córrego Areias, ca $1 \mathrm{~km}$ SE from Bairro da Serra, on road from Apiaí to Iporanga. Hemipsilichthys nimius: Holotype. Brazil: Rio de Janeiro State: Parati: Perequê-Açu basin: MCP 33049, male, $105.1 \mathrm{~mm} \mathrm{SL}$; rio Carrasquinho below the Cachoeira do Tobogã at Penha, ca. $7.5 \mathrm{~km}$ West of highway BR101, on road from Parati to Cunha. Paratype. MCP 31990, 11, 45.7-98.1 mm SL; collected with the holotype. Isbrueckerichthys epakmos: Holotype. Brazil: São Paulo State: Tapiraí: rio Ribeira de Iguape basin: MZUSP 79804, male, 103.1 mm SL; rio Verde at Piúva, on road to Rio Verde. MCP 28276, 63, 39.5-83.3 mm SL; rio Coruja, tributary to rio Juquiá, on road from Tapiraí to Juquiá near Cachoeira do Chá.

\section{Acknowledgments}

I thank Roberto E. Reis (MCP) and Paulo H. Franco Lucinda (UNT) for comments and suggestions on the manuscript. Special thanks to Luiz F. Duboc , Vinicius Abilhoa and Rodrigo Torres for their enthusiastic dedication to field work. José F. Pezzi da Silva prepared all figures. This research is partially financed by CAPES with a doctoral fellowship. Fieldwork supported by All Catfish Species Inventory (NSF DEB-0315963).

\section{Literature Cited}

Armbruster J. W. 2004. Phylogenetic relationships of the suckermouth armoured catfishes (Loricariidae) with emphasis on the Hypostominae and the Ancistrinae. Zoological Journal of the Linnean Society 141: 1-80.

Derijst, E. 1996. Note on the type species of the mailed catfish genus Hemipsilichthys Miranda Ribeiro, 1918 (Pisces: Siluriformes; Loricariidae), with the introduction of Isbrueckerichthys nom. nov. Aquarium Wereld, 49: 62-64. 
Gosline, W. A. 1947. Contributions to the classification of the loricariid catfishes. Arquivos do Museu Nacional, 41: 79-134.

Miranda Ribeiro, A. 1918. Hemipsilichthys, Eigenmann \& Eigenmann e generos alliados. Revista da Sociedade Brasileira de Sciencias 2: 101-107.

Montoya-Burgos, J. I. 2001. Phylogenetic relationships of the Hypostominae (Siluriformes: Loricariidae) with investigations on the phylogeny and evolution of the catfishes. Unpublished D. Ph. D. Thesis, University of Genève.

Montoya-Burgos, J. I., S. Muller, C. Weber \& J. Pawlowski, 1998. Phylogenetic relationships of the loricariidae (Siluriformes) based on mitochondrial rRNA gene sequences. Pp. 363-374. In: L. R.

Pereira, E. H. L. \& R. E. Reis, 2002. Revision of the loricariid genera Hemipsilichthys and Isbrueckerichthys (Teleostei: Siluriformes), with description of five new species of Hemipsilichthys. Ichthyological Exploration of Freshwaters, 13:97-146.

Pereira, E. H. L., R. E. Reis, P. F. M. Souza \& H. Lazzarotto. 2003. A new species of the loricariid catfish genus Hemipsil- ichthys from southern Rio de Janeiro coastal rivers, southeastern Brazil (Teleostei: Siluriformes). Zootaxa, 285: 1-10.

Reis, R. E., J. W. Armbruster \& E. H. L. Pereira. (in press). A new loricariid catfish subfamily (Teleostei, Siluriformes), with revisions of Delturus and Hemipsilichthys. Zoological Journal of the Linnean Society.

Regan, C. T. 1920. XV - Pisces. Zoological Record [1918], 55: 1-19.

Schaefer, S. A. 1997. The neotropical cascudinhos: systematics and biogeography of the Otocinclus catfishes (Siluriformes: Loricariidae). Proceedings of the Academy of Natural Sciences of Philadelphia, 148: 1-120.

Weber, C. 1985. Hypostomus dlouhyi, nouvelle espèce de poisson-chat cuirassé du Paraguay (Pisces, Siluriformes, Loricariidae). Revue Suisse de Zoologie, 92 (4): 955-968.

Received January 2005 Accepted May 2005 